CZASOPISMO INŻYNIERII LĄDOWEJ, ŚRODOWISKA I ARCHITEKTURY

JOURNAL OF CIVIL ENGINEERING, ENVIRONMENT AND ARCHITECTURE

JCEEA, t. XXXIV, z. 64 (3/II/17), lipiec-wrzesień 2017, s. 335-348, DOI:10.7862/rb.2017.176

Mateusz SZARATA ${ }^{1}$

Lesław BICHAJŁO ${ }^{2}$

\title{
DOSTOSOWANIE ORGANIZACJI RUCHU DROGOWEGO I PRZESTRZENI ULIC DO NOWEJ FUNKCJI NA OBSZARACH OBJĘTYCH PROCESAMI REWITALIZACJI
}

\begin{abstract}
W artykule opisano badania prędkości i struktury kierunkowej pojazdów na ulicy Architektów w Rzeszowie. Ulicę zaprojektowano dla obsługi ruchu lokalnego, natomiast jest także wykorzystywana dla ruchu tranzytowego. Celem badań było określenie rozkładu prędkości pojazdów oraz określenie udziału pojazdów tranzytowych w całkowitym ruchu drogowym na ulicy. Wyniki badania posłużyły do opracowania koncepcji uspokojenia ruchu ze względu na zwiększone zagrożenie bezpieczeństwa ruchu drogowego. Wyniki badań i wnioski $\mathrm{z}$ analizy świadczą o konieczności wykonywania prognoz ruchu zaawansowanymi metodami w celu odpowiedniego zaprojektowania ciągów komunikacyjnych eliminujących ruch tranzytowy z ulic osiedlowych niedostosowanych do takiego ruchu.
\end{abstract}

Słowa kluczowe: strefy uspokojenia ruchu, organizacja ruchu drogowego, bezpieczeństwo ruchu, ruch pieszy i rowerowy, modele symulacyjne ruchu drogowego

\section{Wstęp}

Dynamiczny rozwój najważniejszych ośrodków miejskich w Polsce sprawia, że przedmieścia na których pierwotnie zlokalizowany był przemysł zostają wchłonięte przez miasto, a firmy przenoszą się na peryferia (do stref ekonomicznych), które są lepiej skomunikowane z główną siecią drogową regionu i kraju. Taki kierunek rozwoju sprawia, że obszary poprzemysłowe, które niejednokrotnie zlokalizowane są blisko śródmieścia zmieniają swoją funkcje i zostają przekształcone na osiedla mieszkaniowe. Zmiana funkcji użytkowania

1 Autor do korespondencji/corresponding author: Mateusz Szarata, Politechnika Rzeszowska, Zakład Dróg i Mostów, al. Powstańców Warszawy 12, 35-959 Rzeszów; tel.: 17743 2393; e-mail:matsza@prz.edu.pl

${ }^{2}$ Lesław Bichajło, Politechnika Rzeszowska, Zakład Dróg i Mostów, al. Powstańców Warszawy 12,35-959 Rzeszów; tel.: 17743 2396, e-mail: leszbich@prz.edu.pl 
obszaru stawia przed zarządcami miast wyzwania związane z rozbudową i przebudową sieci drogowej. Jednym z istotnych elementów tych prac powinno być uwzględnienie rozwiązań z zakresu zarządzania ruchem prowadzonym w nowym zagospodarowaniu, w tym przede wszystkim zarzadzaniem dostępnością dla pojazdów ciężkich oraz zarządzaniu prędkością pojazdów. Jednym z możliwych sposobów jest uspokajanie ruchu w obszarach zamieszkania, co powinno wpłynąć pozytywnie na zmniejszenie zagrożenia użytkowników drogi. Uspokojenie ruchu jest zadaniem złożonym, dotychczas kojarzonym głównie z punktowym rozmieszczaniem progów zwalniających lub wprowadzaniem ograniczeń prędkości. Wykorzystując doświadczenia krajów europejskich można zaproponować i wdrażać skuteczne rozwiązania poprawiające bezpieczeństwo i komfort życia mieszkańców osiedli, gdzie ruch drogowy będzie dyscyplinowany nie tylko poprzez znaki drogowe, ale również przez odpowiednie ukształtowanie jezdni oraz jej otoczenia [1][2]. Jednym z najważniejszych celów uspokojenia ruchu jest zapewnienie bezpiecznej prędkości za pomocą środków uspokojenia ruchu, wymuszającego na kierowcach egzekwowanie ograniczeń prędkości. Do takich środków można zaliczyć odpowiednie kształtowanie geometrii jezdni i wprowadzanie elementów organizacji ruchu przyczyniających się do bardziej spokojnej jazdy. Uspokojenie ruchu przynosi najwięcej korzyści pieszym i rowerzystom, czyli niechronionym uczestnikom ruchu, którzy ponoszą największe ryzyko związane z wypadkiem. Kolejnym ważnym elementem uspokojenia ruchu jest ograniczenie ruchu tranzytowego $\mathrm{z}$ osiedli poprzez zniechęcanie kierowców do przejeżdżania przez dany obszar za pomocą środków uspokajania ruchu

W artykule przeprowadzono analizy organizacji i warunków ruchu drogowego na osiedlu powstającym przy zbiegu ulic Architektów i ul. Przemysłowej Rzeszowie. Przeprowadzono badania ruchu na ul. Architektów obejmujące natężenie ruchu, strukturę rodzajową pojazdów oraz odcinkowy pomiar prędkości. W związku z tym, że osiedle jest w ciągłej rozbudowie i w planach układ drogowy ma ulec znaczącej zmianie, w opracowaniu wykorzystane zostały również makrosymulacyjne modele ruchu drogowego pozwalające zaprognozować zmiany warunków ruchu na nowo powstającym osiedlu. Głównym celem przeprowadzonych prac było zaproponowanie kompleksowego rozwiązania strefy uspokojenia ruchu, przyczyniającej się do poprawy jakości życia mieszkańców.

\section{Stan istniejący}

Nowo powstałe osiedle stanowi kompleks 19 bloków zlokalizowanych wzdłuż ul. Architektów i ul. Solidarności. Na terenie osiedla oprócz obiektów handlowych zlokalizowane są również dwa przedszkola i żłobek. Główną ulicą osiedla jest ul. Architektów, która z jednej strony łączy się z ul. Przemysłową a $\mathrm{z}$ drugiej strony $\mathrm{z}$ ul. Zawiszy Czarnego. Pełni ona funkcję ulicy zbiorczej osiedla, do niej prowadzi ul. Solidarności, a za pomocą 4 zjazdów połączono 
parkingi i wewnętrzne drogi osiedlowe. W przekroju poprzecznym oprócz jezdni składającej się z dwóch pasów ruchu o łącznej szerokości 6m znajdują się również parkingi przykrawężnikowe umożliwiające parkowanie prostopadłe i chodniki. Przy wjeździe na ul. Architektów od strony ul. Przemysłowej prędkość ograniczono oznakowaniem do $30 \mathrm{~km} / \mathrm{h}$. Około $200 \mathrm{~m}$ dalej, na linii bloków ustawiono kolejny znak D-40 informujący o wjeździe do strefy zamieszkania. Taki sam znak został ustawiony na początku ul. Architektów od strony ul. Zawiszy Czarnego. Znak od strony ul. Zawiszy jest trudny do zauważenia przez kierowców (rys. 1.). Do osiedla doprowadzono dwie linie autobusowe, które kursują wzdłuż ul. Architektów.

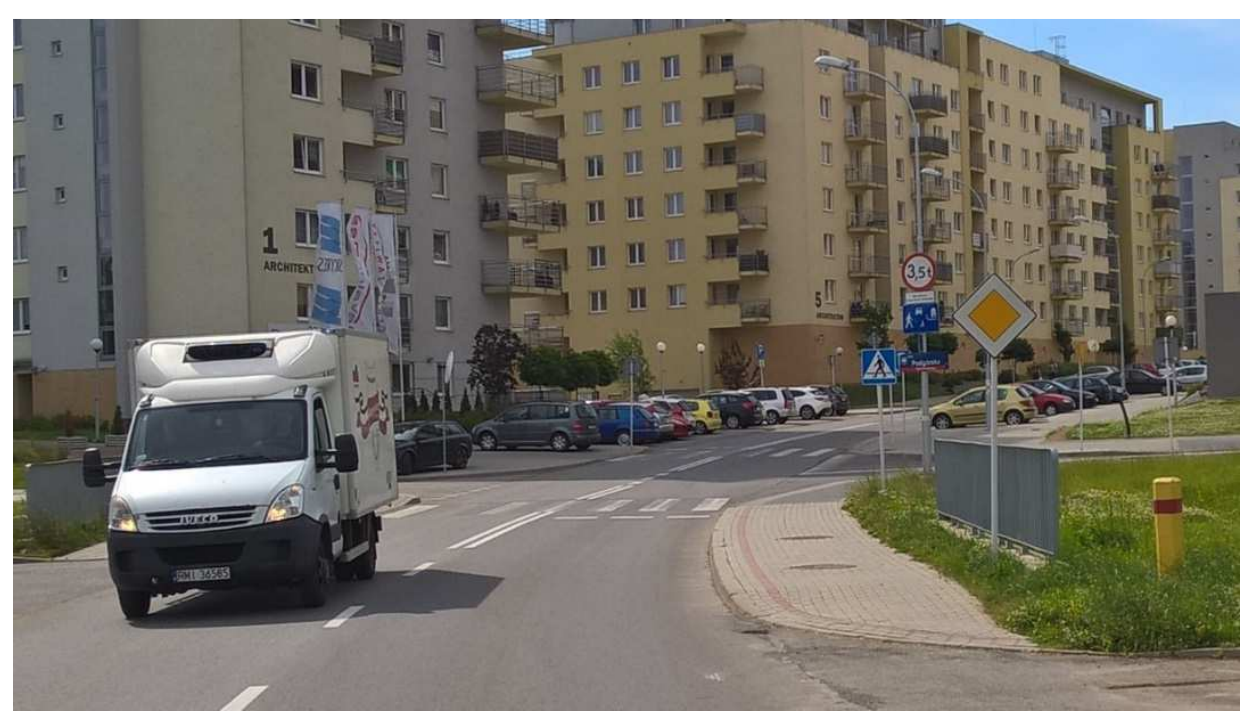

Rys. 1. Ulica Architektów - wjazd na teren osiedla od ul. Przemysłowej (Źródło własne)

Fig. 1. The Architektów street - general view from the Przemysłowa street (Own source)

\section{Analiza warunków ruchu}

W czerwcu 2016 w godzinach szczytu popołudniowego przeprowadzono pomiary ruchu drogowego, które obejmowały pomiar:

- natężenia ruchu na wjeździe do osiedla (punkty P1 i P3),

- struktury rodzajowej,

- ruchu tranzytowego,

- prędkości (punkt P2).

W pomiarach ruchu wykorzystano kamery wideo rejestrujące natężenie ruchu w punktach P1 i P3 oraz automatyczny detektor ruchu zlokalizowany w punkcie P2, wyznaczający prędkość chwilową pojazdów (rys. 2-4). 


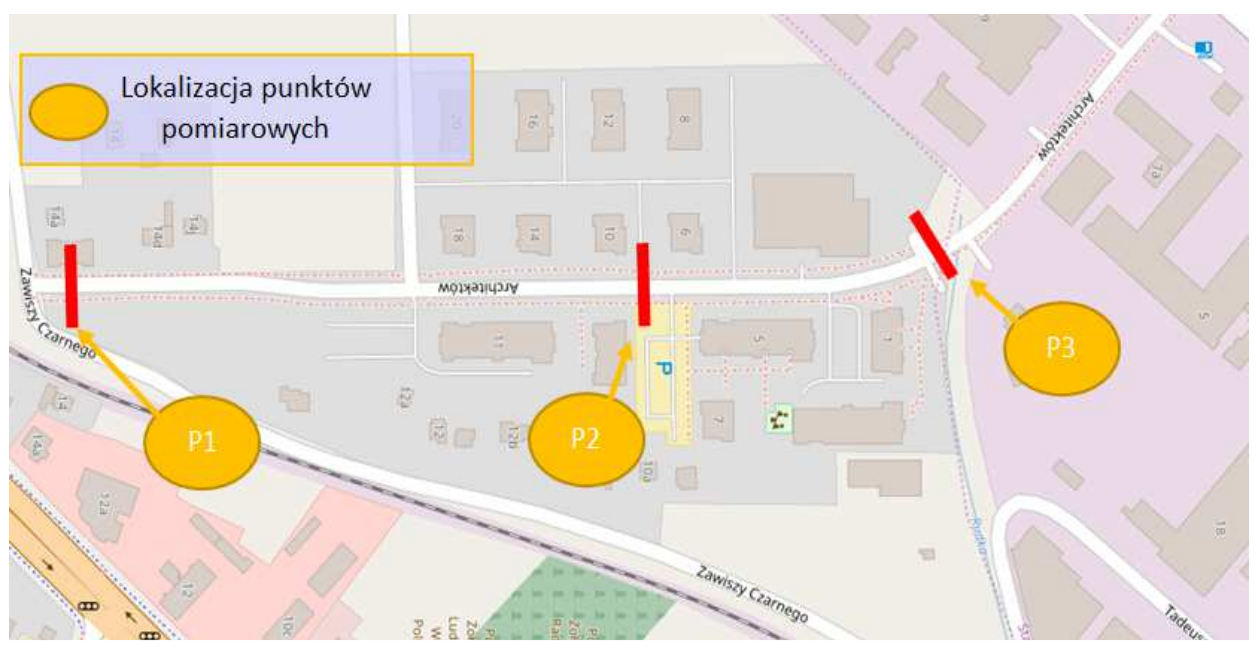

Rys. 2. Lokalizacja punktów pomiarowych (Opracowanie własne na podstawie openstreetmap)

Fig. 2. The measuring points localization (Own study based on openstreetmap)

W wyniku przeprowadzonych badań wyznaczono natężenie ruchu pojazdów wjeżdżających na osiedle. Od strony centrum liczba pojazdów wjeżdżających na osiedle wyniosła w sumie $365 \mathrm{P} / \mathrm{h}$, z czego $67 \%$ pojazdów kierowała się w stronę osiedla, a 33\% w stronę centrum. Od strony ul. Zawiszy Czarnego w punkcie P1 liczba zanotowanych pojazdów wyniosła $294 \mathrm{P} / \mathrm{h}$. W tym przypadku $60 \%$ pojazdów wyjeżdżało a $40 \%$ pojazdów kierowało się w stronę osiedla. W strukturze rodzajowej pojazdów występują głównie samochody osobowe (94\%), zaobserwowano też niewielki udział samochodów dostawczych (3\%), motocykli (2\%) i autobusów komunikacji miejskiej (1\%). Na podstawie zarejestrowanego obrazu z kamer rozmieszczonych na analizowanym odcinku możliwe było zliczenie liczby pojazdów, które przejeżdżały przez osiedle. Ruch tranzytowy zaobserwowany na osiedlu stanowi 39\% całkowitego natężenia ruchu. W obu kierunkach w ciągu godziny szczytu zaobserwowano 144 pojazdy przejeżdżające przez osiedle, $\mathrm{z}$ czego prawie $80 \%$ pojazdów kierowało się w stronę ul. Zawiszy. Zlokalizowany $\mathrm{w}$ punkcie P2 detektor radarowy pozwolił na sprawdzenie prędkości z jakimi poruszały się pojazdy. Pomiar prędkości wykonywano w bezpośrednim sąsiedztwie przejścia dla pieszych (odległość od przejścia wynosiła $30 \mathrm{~m}$ (rys. 4.)). W celu wyznaczenia średniej prędkości i odrzucenia odstających wyników dla zebranych pomiarów wyznaczono przedział ufności. Dla przyjętego prawdopodobieństwa $\mathrm{P}=95 \%$ określono górną i dolną granicę przedziału, a następnie wyznaczono średnią prędkość wynoszącą $41 \mathrm{~km} / \mathrm{h}$. Przeprowadzone badania pokazały, że tylko $12 \%$ pojazdów stosuje się do obowiązującego ograniczenia prędkości wynikającego z oznakowania „strefa zamieszkania". 


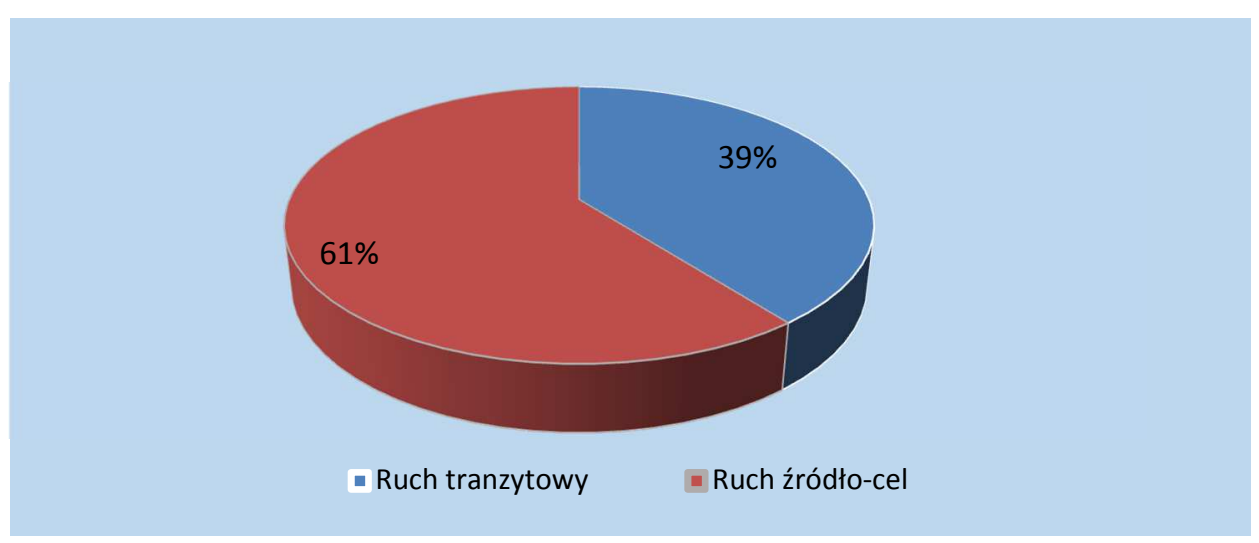

Rys. 3. Ruch lokalny i tranzytowy na badanej ulicy (Opracowanie własne)

Fig. 3. The local and transit traffic on the street (Own study)

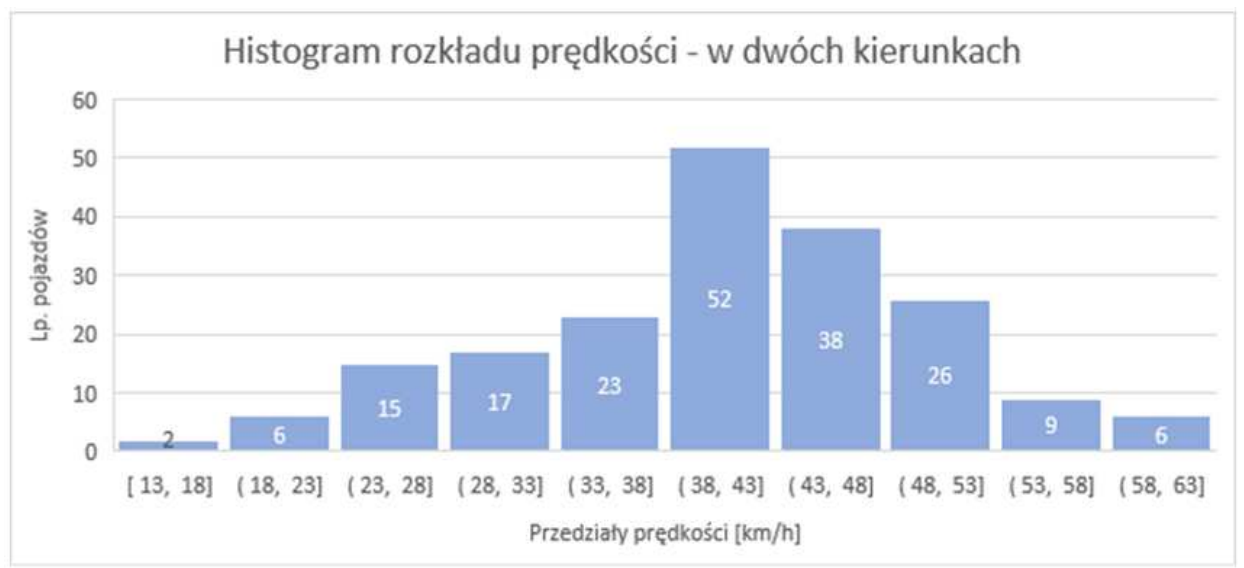

Rys. 4. Histogram rozkładu prędkości w dwóch kierunkach (opracowanie własne)

Fig. 4. The traffic velocity histogram (both direction collection)

\section{Prognoza zmian potoków ruchu}

Zmiana funkcji obszaru i intensywna rozbudowa osiedla wymusza dostosowanie infrastruktury drogowej do większego ruchu, który generuje ten obszar. $\mathrm{W}$ związku z tym powstały plany rozbudowy sieci ulic osiedla. Jedną z planowanych do rozbudowy jest ul. Solidarności (odcinek „D1”), która ma zapewnić dodatkowe połączenie osiedla z ul. Przemysłową. Drugą planowaną inwestycją ma być połączenie ul. Architektów z ul. Zawiszy Czarnego (odcinek „D2”) ułatwiając w ten sposób dojazd do ul. Podkarpackiej. Kolejną ważną planowaną inwestycją jest budowa równoległej do ul. Architektów drogi łączącej ul. Zawiszy Czarnego z ul. Architektów (odcinek „D3”). 


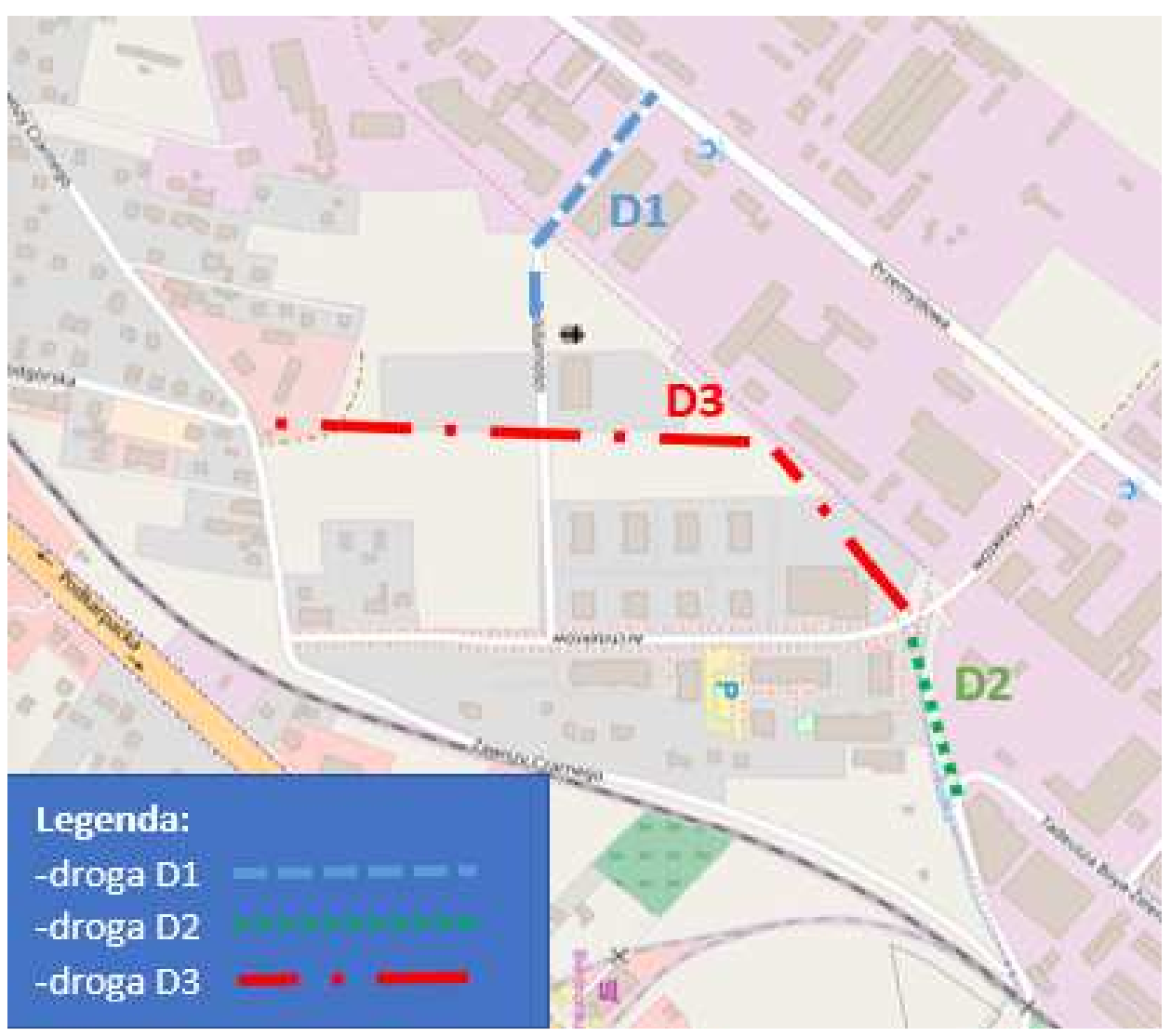

Rys. 5. Planowana rozbudowa układu komunikacyjnego osiedla (Opracowanie własne na podstawie openstreetmap)

Fig. 5. The development of the connection streets on the residential area (Own study based on openstreetmap)

Koncepcje strefy uspokojenia ruchu musi uwzględnić wszelkie zmiany w sieci drogowej osiedla. W tym celu opracowano prognozę rozkładu potoków ruchu. Wykorzystano makrosymulacyjny model Rzeszowa z 2015r, który powstał w oparciu o klasyczny czterostadiowy model ruchu [3-5], składający się z następujących etapów:

a. generacji podróży - podczas której definiuje się liczbę tzw. potencjałów ruchotwórczych, które odpowiadają za podróże generowane i absorbowane pomiędzy rejonami komunikacyjnymi (obszary o jednorodnych zachowaniach komunikacyjnych) w mieście,

b. dystrybucji podróży - polega na przestrzennym rozkładzie produkcji rejonów komunikacyjnych, obrazującym skąd - dokąd są realizowane podróże. W efekcie uzyskuje się więźbę ruchu, stanowiącą macierz o wymiarze odpowiadającym liczbie rejonów komunikacyjnych, 
c. podziału na środki transportu (tzw. modalsplit) - wyznacza udział poszczególnych środków transportu w podróżach. Ze względu na ograniczony zakres badań przyjętych do analiz w proponowanym podejściu analizowano wyłącznie komunikację indywidualną,

d. rozkładu ruchu na sieć komunikacyjną - przy pomocy programu symulacyjnego i dla opracowanego modelu sieciowego miasta, zostanie dokonany rozkład więźby ruchu co w efekcie pozwoli wyznaczyć wielkości potoków pojazdów na poszczególnych odcinkach sieci.

Prognozę zmian w potokach ruchu przeprowadzono poprzez aktualizację modelu makrosymulacyjnego Rzeszowa uwzględniającą wyniki przekrojowych pomiarów natężenia ruchu uzyskanych w trakcie badań oraz plan istniejącej i perspektywicznej sieci drogowej osiedla. Zaktualizowano również potencjały ruchotwórcze na podstawie zebranych danych statystycznych dotyczących liczby mieszkańców osiedla. Po wprowadzeniu zmian do modelu bazowego ponownie przeprowadzono proces rozkładu ruchu na sieć drogową. W wyniku prac otrzymano nowy rozkład ruchu (rys. 6).

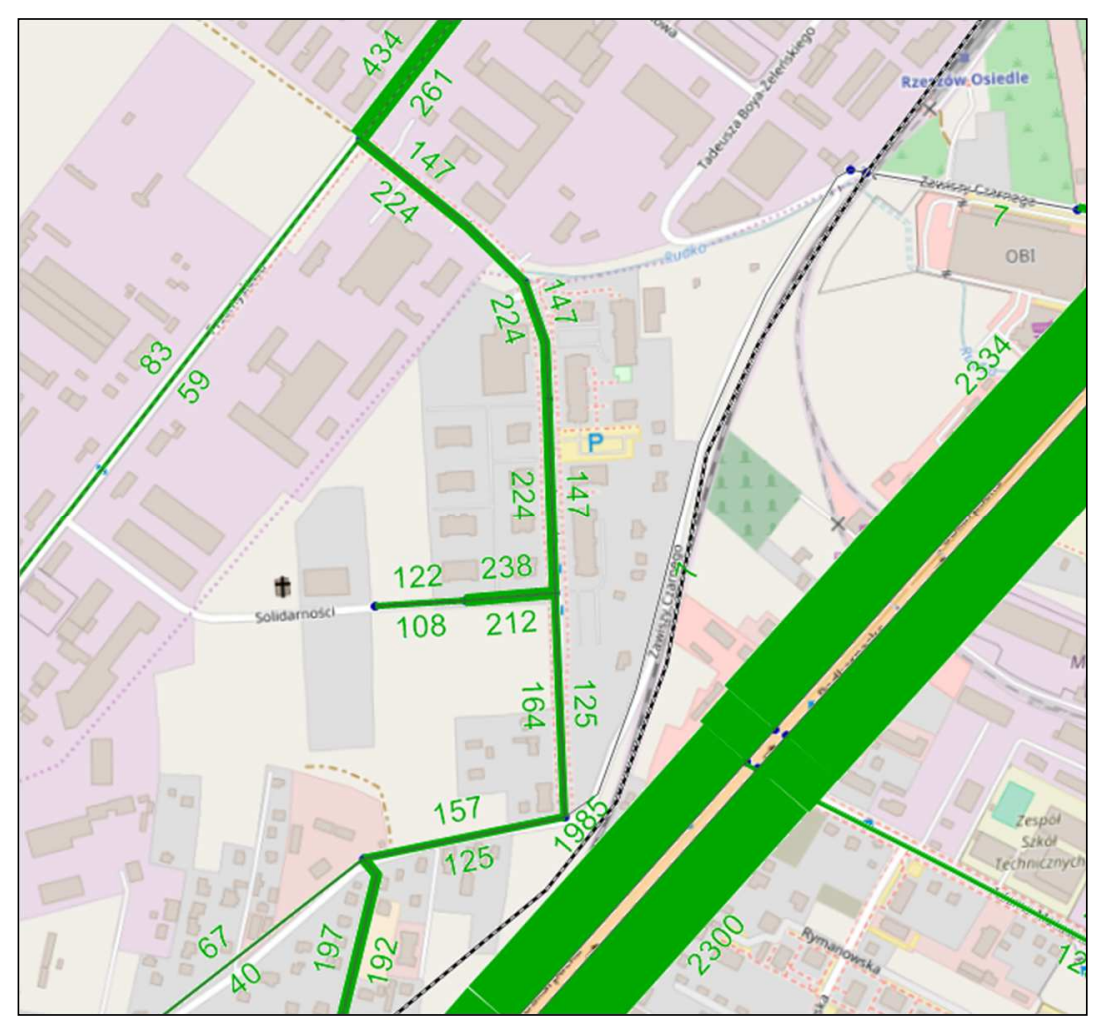

Rys. 6. Rozkład ruchu na dotychczasowej sieci drogowej (Opracowanie własne)

Fig. 6. The current traffic distribution (Own study) 
W kolejnym kroku założono trzy warianty rozbudowy sieci ulicznej osiedla i wprowadzono je do modelu wykonując nowe rozkłady ruchu. W analizach przyjęto założenie, że nowa sieć drogowa powstanie w ciągu 5 lat.

Wariant 1 zakłada budowę drogi osiedlowej D3 o parametrach technicznych takich samych jakie posiada ul. Architektów. Nowo wybudowany ciąg drogowy poprawi komunikację wewnątrz osiedla. Budowa odcinka znacząco wpłynie na odciążenie ul. Architektów. Rozkład ruchu pokazuje, że nowy odcinek może stać się również bardziej atrakcyjny dla ruchu tranzytowego przejeżdżającego przez osiedle (rys. 7.).

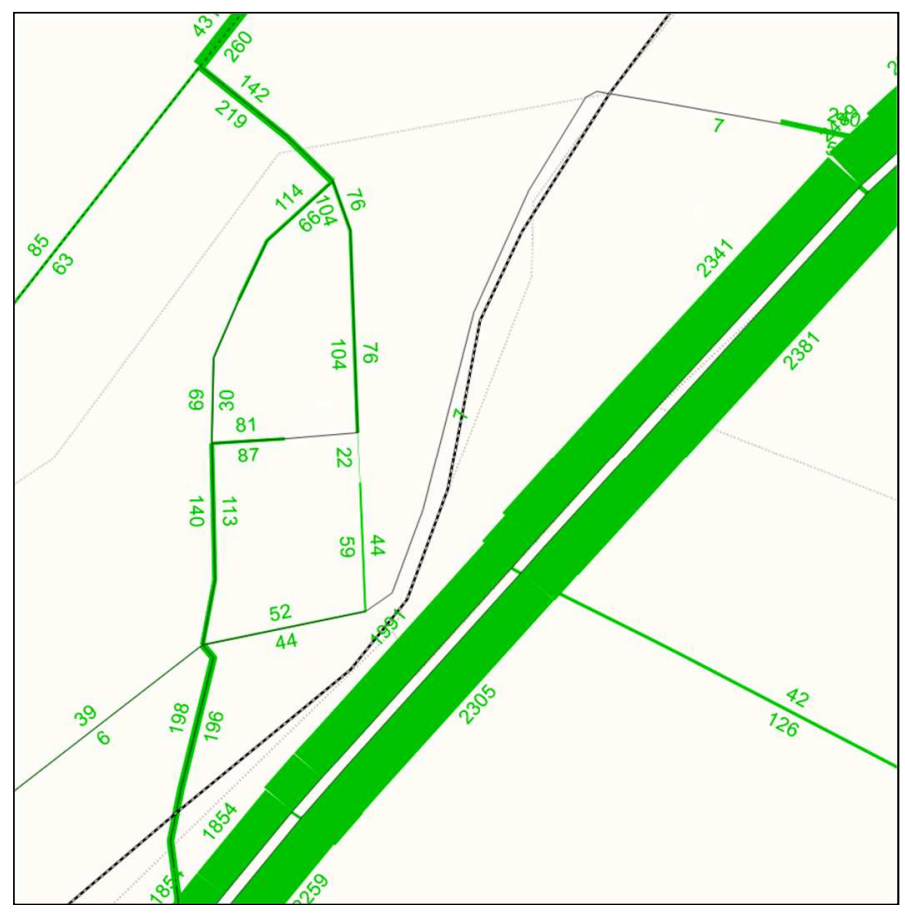

Rys. 7. Rozkład potoków ruchu dla wariantu 1 rozwoju sieci drogowej (Opracowanie własne)

Fig. 7. The predicted traffic distribution in variant 1 of the road network development (Own study)

W wariancie 2 założono rozbudowę sieci osiedla o drogi D3 i D2. Budowa drogi D2 umożliwi dojazd do ul. Podkarpackiej i może wprowadzić nowe zachowania komunikacyjne nie tylko mieszkańców osiedla stanowiąc alternatywną drogę dojazdu do ul. Przemysłowej. W modelu wylot z ul. Architektów w stronę ul. Przemysłowej jest obciążony o $30 \%$ większym natężeniem ruchu w stosunku do poprzedniej sytuacji. Omawiany odcinek przejmie również dodatkowy ruchu pojazdów, które dotychczas wykorzystywały wąską ul. Zawiszy Czarnego. Wy- 
nika to z omijania kolejki pojazdów na ul. Podkarpackiej w kierunku centrum. Natężenie ruchu na ul. Zawiszy Czarnego w dużej mierze ograniczone jest przez warunki techniczne tego odcinka. W analizach założono, że ulica nie zmieni swojego przekroju poprzecznego i nie zostanie rozbudowana o dodatkowy pas ruchu i ciąg pieszy. Obecnie przekrój uliczny składa się z jezdni o szerokości $3,5 \mathrm{~m}$ oraz poboczy gruntowych. Jak pokazywały analizy przepustowości ten łącznik byłby chętniej wybierany przez kierowców w przypadku zapewnienia lepszych warunków ruchu (rys. 8.).

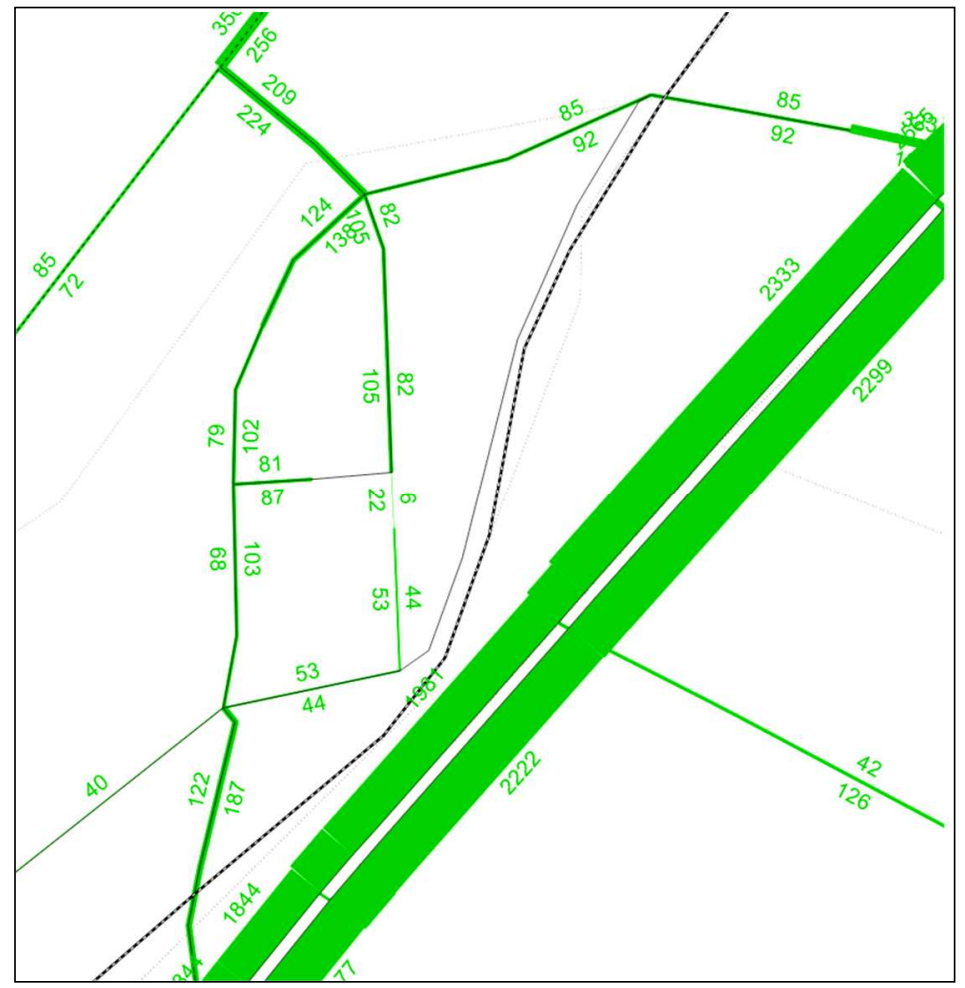

Rys. 8. Rozkład potoków ruchu dla wariantu 2 rozwoju sieci drogowej (Opracowanie własne)

Fig. 8. The predicted traffic distribution in variant 2 (Own study)

Wariant 3 zakłada powstanie drogi osiedlowej „D3”, łącznika ul. Architektów z ul. Podkarpacką „D2” oraz przedłużenie ul. Solidarności „D1” umożliwiając $w$ ten sposób dodatkowe połączenie osiedla $\mathrm{z}$ ul. Przemysłową. Jak wynika $\mathrm{z}$ modelu $\mathrm{w}$ szczycie popołudniowym, nowe połączenie stanie się atrakcyjne głównie dla kierowców opuszczających osiedle. Analizując zmiany potoków ruchu na ulicach osiedlowych możemy zauważyć wzrost natężenia ruchu na wjeździe do osiedla od strony ul. Zawiszy stąd możemy wywnioskować, że do- 
datkowy ruch przyczyni się do wzrostu ruchu tranzytowego pomiędzy ul. Podkarpacką a ul. Przemysłową (rys. 9.).

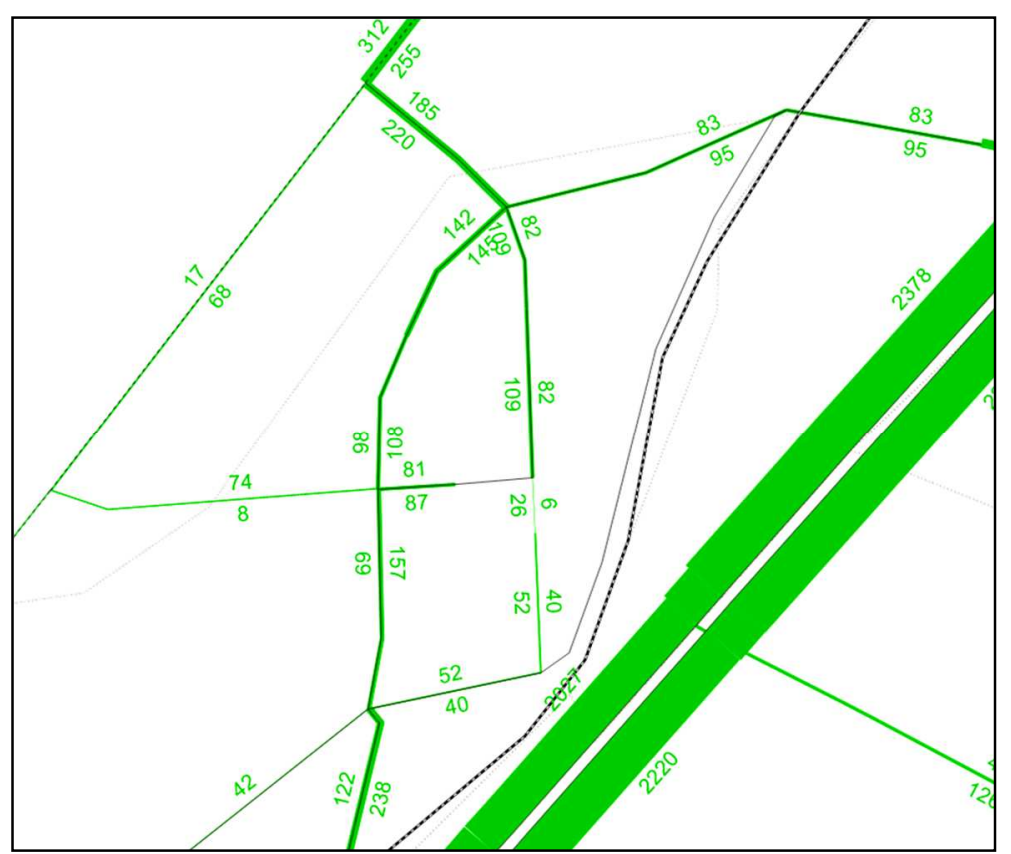

Rys. 9. Rozkład potoków ruchu dla wariantu 3 rozwoju sieci drogowej (Opracowanie własne)

Fig. 9. The predicted traffic distribution in variant 3 (Own study)

\section{Proponowane rozwiązania dla poprawy bezpieczeństwa użytkowników drogi i mieszkańców osiedla}

Przeprowadzona analiza ruchu na osiedlu i opracowane warianty prognostyczne rozwoju sieci drogowej osiedla pozwoliły zaproponować koncepcje strefy uspokojenia ruchu. Dobór środków uspokojenia ruchu jest zależny od funkcji drogi, parametrów technicznych i charakteru otoczenia drogi. Jednym z narzędzi, które można zaproponować dla analizowanego obszaru jest związane ze strefowaniem prędkości. Na drogach o charakterze zbiorczym zaprojektowano ograniczenie prędkości do $30 \mathrm{~km} / \mathrm{h}$, a na ulicach wewnętrznych i parkingach osiedlowych, gdzie ze względów bezpieczeństwa maksymalna prędkość pojazdów powinna być w przybliżeniu zrównana z prędkością ruchu pieszego zaprojektowano oznakowanie ,strefa zamieszkania”. Jak pokazują wyniki przeprowadzonych badań ruchu na ul. Architektów ustawienie jedynie znaków ograniczających prędkość ruchu jest niewystarczające, dlatego niezależnie od tego na 
wjeździe do obszaru uspokojenia ruchu zaproponowano wprowadzenie bramownic, aby kierowcy mieli większą świadomość tego, że poruszają się w obszarze, w którym obowiązuje ograniczenie prędkości. Geometria typowych bramownic wprowadza zakrzywienie toru jazdy, a zmiana nawierzchni i otoczenia pozwala podkreślić fakt, że kierowcy wjeżdżają do strefy uspokojenia ruchu. Ponadto zaprojektowano wyniesienie nad poziom jezdni ul. Architektów powierzchni skrzyżowań i wybranych przejść dla pieszych w rejonie placów zabaw i przedszkoli, wraz ze zmianą koloru i materiału dla warstwy ścieralnej. Wprowadzone rozwiązania będą wymuszać ostrożną jazdę w miejscach szczególnie niebezpiecznych i dostosowanie prędkości do obowiązujących ograniczeń. Ponadto wprowadzone rozwiązania obniżające prędkość powinny wpłynąć korzystnie na zmniejszenie ruchu tranzytowego i zniechęcać kierowców do przejazdu przez strefę ograniczenia prędkości. Proponowane rozwiązania mogą być również przyjazne transportowi publicznemu poprzez właściwe ukształtowanie bramownic, skrzyżowań i wyniesionych przejść dla pieszych umożliwiając sprawny i komfortowy przejazd autobusom komunikacji miejskiej [6-8] (rys. 10-12).

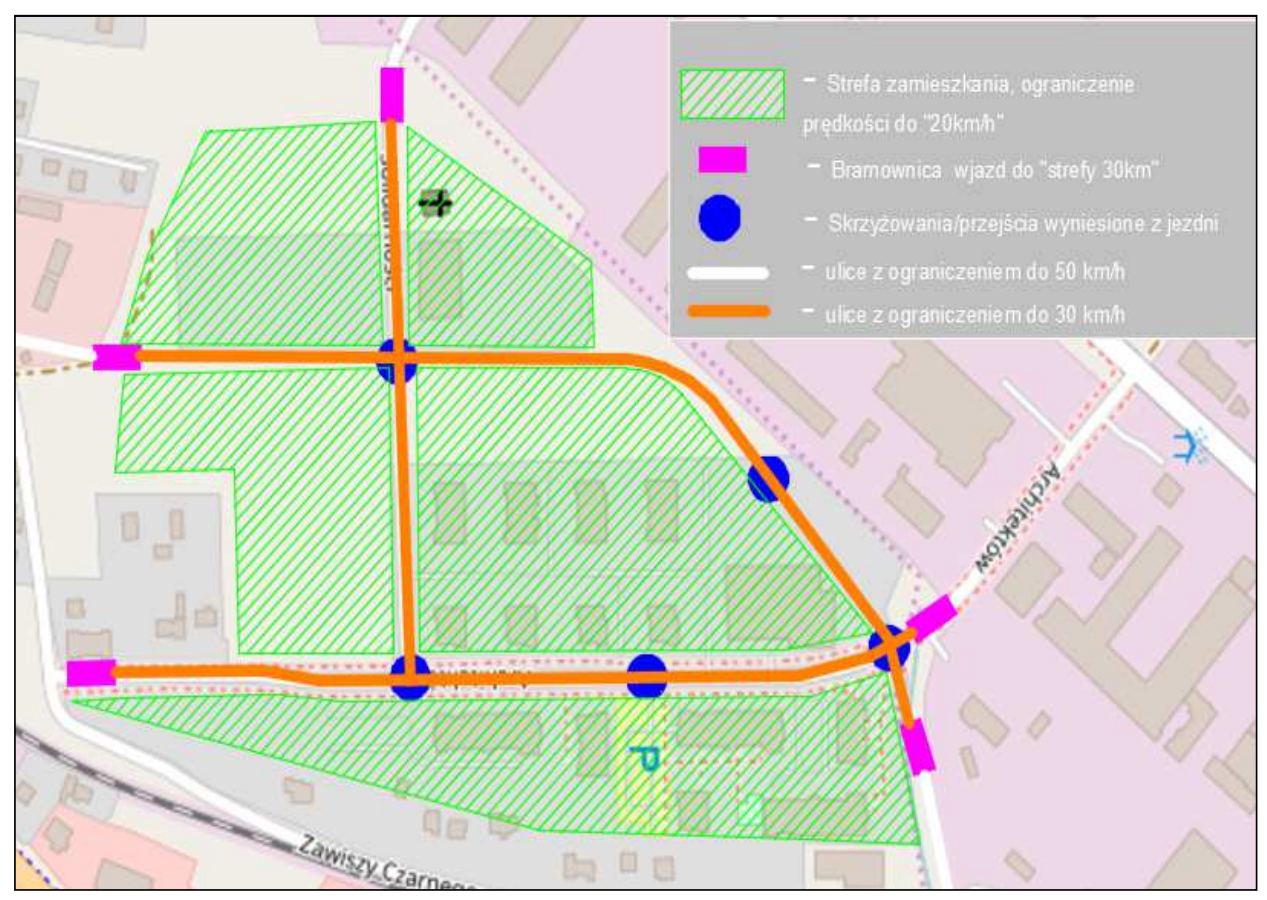

Rys. 10. Koncepcja strefy „ruchu uspokojonego” (Opracowanie własne na podstawie openstreetmap)

Fig. 10. The conception of slow-motion area(Own study based on openstreetmap) 


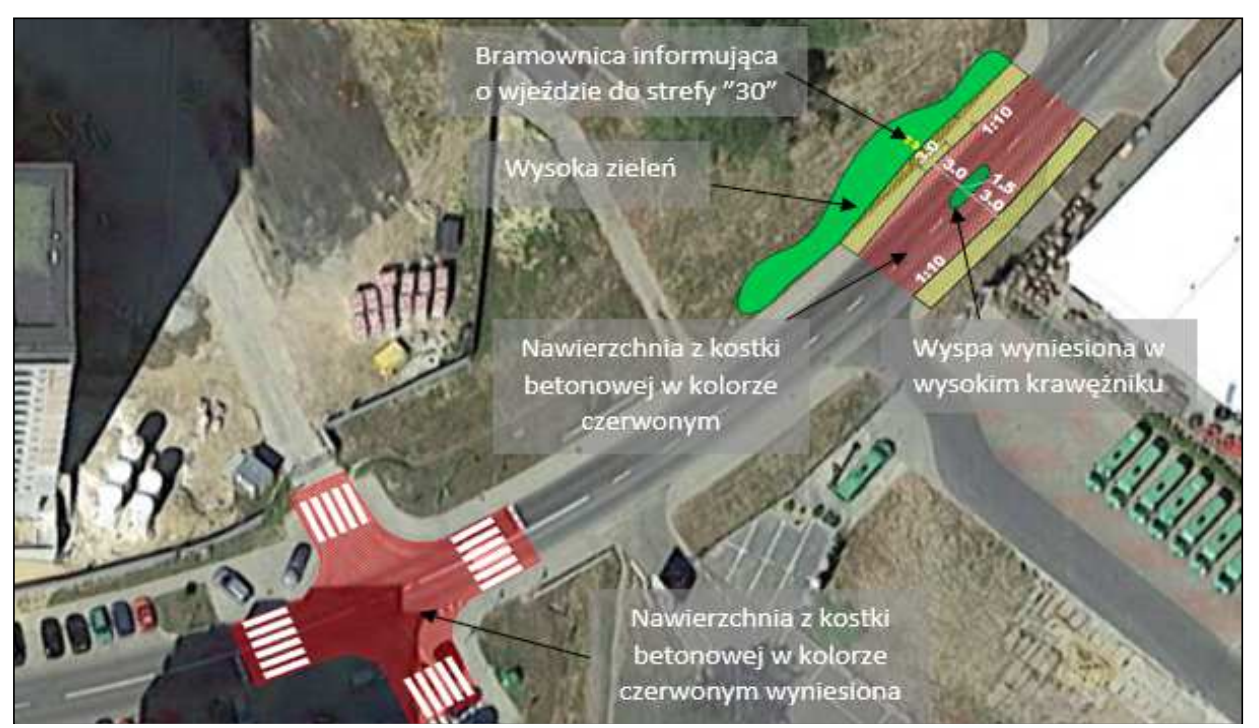

Rys. 11. Propozycja strefy „ruchu uspokojonego” - wjazd od stronu ul. Przemysłowej (opracowanie własne na podstawie map gogle)

Fig. 11. The detail of slow-motion area entrance at Przemysłowa street (Own study based on gogle maps)

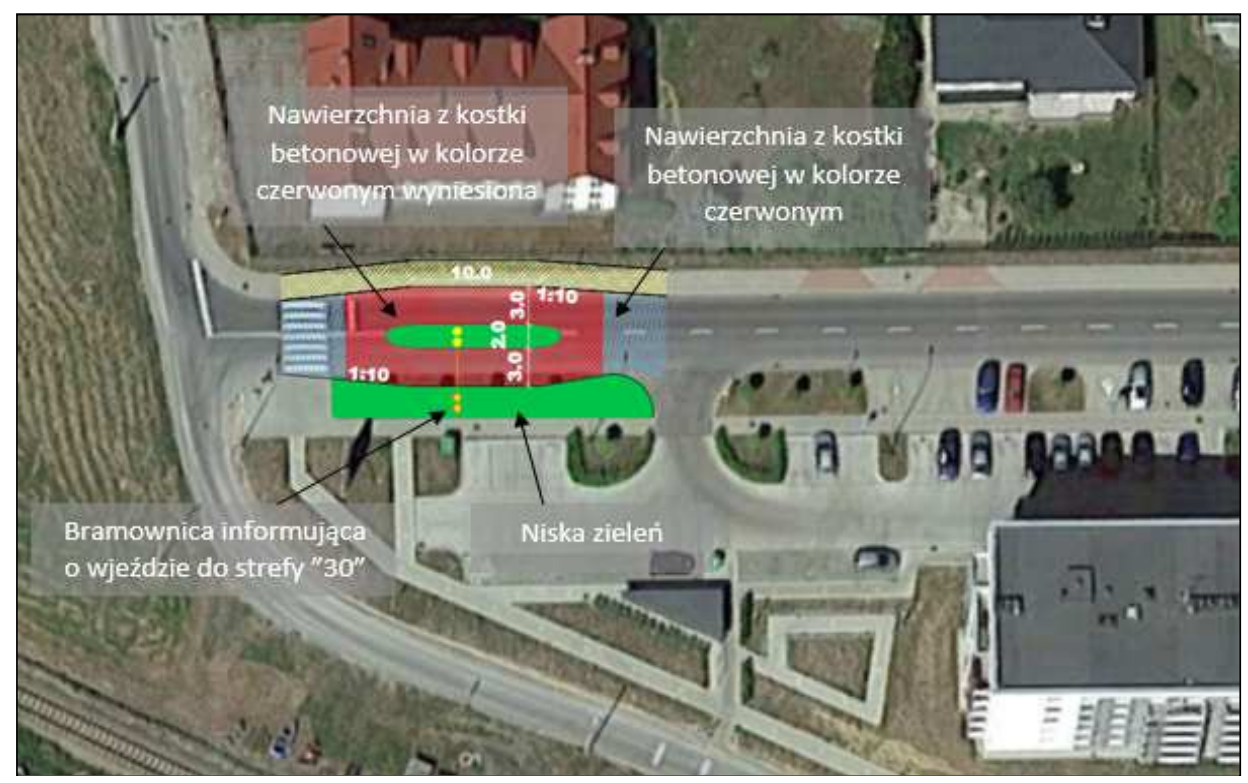

Rys. 12. Propozycja strefy „ruchu uspokojonego” - wjazd od stronu ul. Zawiszy Czarnego (opracowanie własne na podstawie map gogle)

Fig. 12. The detail of slow-motion area entrance - at Zawiszy Czarnego street(Own study based on gogle maps) 


\section{Podsumowanie}

$\mathrm{W}$ artykule podjęto problematykę projektowania zagospodarowania obszarów poprzemysłowych, adaptowanych jako tereny mieszkaniowe. Nieuwzględnienie możliwego rozkładu ruchu z dużym udziałem ruchu tranzytowego prowadzi do zwiększenia zagrożenia bezpieczeństwa ruchu drogowego. Dotyczy to przede wszystkim nadmiernej prędkości pojazdów tranzytowych. Ich kierowcy są zainteresowani skróceniem czasu podróży. Ich przejazd przez osiedle oznacza, że wybierają tę tras przejazdu mimo niedogodności i zagrożenia bezpieczeństwa ruchu drogowego spowodowanego obecnością pieszych, rowerzystów, dzieci oraz manewrami pojazdów korzystających z parkingów przyległych do drogi. Zagrożenie takimi sytuacjami można przewidzieć wykonując modelowanie ruchu przed budową osiedla. Wówczas można przewidzieć właściwą kompozycję geometrii i wyposażenia drogi w tak sposób, aby zapewnić mieszkańcom odpowiedni komfort mieszkania i podróżowania, jednocześnie zapewniając wymaganą użyteczność drogi. Wybrano odcinek badawczy, dla którego sporządzono analizy prędkości i liczby pojazdów, a następnie zaproponowano konkretne rozwiązania z zakresu uspokojenia ruchu. Wykonano także analizy rozkładu ruchu drogowego związane z rozbudową ulic na analizowanym osiedlu.

\section{Literatura}

[1] Ministerstwo Infrastruktury oraz Rijkswaterstaat Limburg - Ministerstwo Komunikacji i Gospodarki Wodnej Królestwa Niderlandów, Oddział Limburg, Holandia, „Podręcznik stref prędkości ograniczonej „30 km/h” - wytyczne dotyczące projektowania i wdrażania”.

[2] United Kingom Department for Transport, Department for Regional Development (Northern Ireland), Scottish Executive Welsh Assembly Government, „Local TransportNote 01/07 Traffic Calming", Crown 2007 r.

[3] Brzeziński A., Waltz A., "Budowa hierarchicznych modeli ruchu w sieciach drogowych", rozprawa doktorska, Politechnika Warszawska, Wydział Inżynierii Lądowej, Warszawa 1998

[4] KBR 2003, Przetwarzanie wyników badań, Moduł: Modelowanie ruchu, Pracownia Badań Społecznych, Sopot 2003"

[5] PTV AG., "Visum User Manual - Analysis and Planningof Transport Networks", PTV Planung Transport Verkehr AG, Karlsruhe 2001

[6] Ministerstwo Infrastruktury i rozwoju, Organizacja przestrzeni ulic w obszarach śródmiejskich, Warszawa 2013

[7] Opracowanie na zlecenie Ministerstwa Infrastruktury, Zasady uspokajania ruchu na drogach za pomocą fizycznych środków technicznych, Ekkom, 2008.

[8] Rozporządzenie Ministra Infrastruktury z dnia 3 lipca 2003 r. w sprawie szczegółowych warunków technicznych dla znaków i sygnałów drogowych oraz urządzeń 
bezpieczeństwa ruchu drogowego i warunków ich umieszczania na drogach (Dz. U.2003 nr 220, poz. 2181, z późn. zm.) - Załącznik nr 4.

\section{THE ROAD TRAFFIC ORGANIZATION AND STREET SPACE ADJUSTMENT FOR THE NEW FUNCTION ON AREA REVITALIZATION PROCCESSES}

\section{S u m m a r y}

The article describes the speed distribution and directional structure of vehicles on the Architektów street in Rzeszow. The street has been designed for local traffic, but it is also used for transit traffic. The results of the study have been used to develop the concept of traffic calming zone due to increase the road safety. The results and conclusions of the analysis demonstrate the necessity to make advanced traffic forecasts for the appropriate design of road network what eliminates transit traffic from unoccupied street traffic.

Keywords: traffic calming zones, road traffic organization, traffic safety, pedestrian and bicycle traffic, traffic simulation

Przestano do redakcji: 25.08.2017 r.

Przyjęto do druku: 01.09.2017 r. 